\title{
Assessing the Institutional Outreach and Sustainability of Micro Finance Institution in Ethiopia: Evidence from Omo Microfinance Institutions Hawassa Branch
}

\author{
Taddesse Shiferaw Deneke \\ General Manager of Taddesse Shiferaw Authorized Accounting firm in Ethiopia
}

\begin{abstract}
Institutional sustainability and outreach are key for achieving the micro finance goal of meeting financial requirement of poor people. So, the objective of this study was to assess the institutional outreach and sustainability of Omo Microfinance Institution at Hawassa branch. To this end, the researchers had used descriptive research design because using this type of research design enables the researchers to assess and describe the present situation of institutional sustainability and outreach of the institution. The primary data was collected from 60 randomly selected employees of OMFI Hawassa branch using structured questionnaire. Then, descriptive statistics analysis has been done through SPSS version 23.0 in order to get the reliable findings. Consequently, the result of the study showed that the factors influencing outreach and sustainability of OMFI Hawassa branch were nature of loan extended to customers, Poor loan management, flexibility of loan repayment schedule, loan defaulting faced by customers, and per customer outstanding. Besides, the study showed that level of sustainability and institutional outreach level is increased by higher deposit mobilization, saving mobilization extended to borrowers, increase in saving amount, and regulatory saving framework for the reason most of the respondents expressed their positive level of agreement with statements asked about this variables. Based on the findings of the study, the researcher forwarded possible recommendations for the OMFI Hawassa branch in order to improve the institutional sustainability in one hand and outreach in other hand.
\end{abstract}

Keywords: Omo Microfinance Institution, Institutional Sustainability, Outreach

DOI: $10.7176 /$ RJFA/11-15-01

Publication date:August $31^{\text {st }} 2020$

\section{Introduction}

\subsection{Background of the study}

Microfinance refers to the delivery of financial services such as credit, savings and insurance for lower income society in the nation. Accordingly, Ethiopian Proclamation No. 626/2009 defines micro financing business as "the provision of financial services like accepting savings extend credit, drawing and accepting drafts payable, providing money transfer services and others specified in the Article 3(2) of the proclamation. Besides, (Alemayehu, 2010), defined microfinance as a provision of financial services to low income clients or solidarity lending groups including consumers and the self-employed, who traditionally lack access to banking and related services.

The two aspects on which OMFIs concentrates are outreach to all society and its sustainability in performing financial services. Outreach- is progress toward the mission of development finance. This mission is to make the lives of poor people better. MFIs do this by producing outreach, loans and deposits used by the poor. It refer to the effort by micro finance organizations to extend loans and financial services to an ever-wider audience (breadth of outreach) and especially toward the poorest of the poor (depth of outreach). Thus, reaching the poorest is depth of outreach, but reaching large number of people even if they are relatively less poor is breadth of outreach. Sustainability- is the ability to repeat outreach in the future MFIs differ from banks because they provide financial services to low income customers and often provide loans based on group based collateral. It can be defined as the capacity of a program to stay financially viable even if subsidies and financial aids are cut off by reducing expenses per loan and increasing the probability of repayment. Hence, studying outreach and sustainability of OMFIs is an important agenda of 21 th century.

\subsection{Statement of the problem}

The prevailing operation of the OMFIs in low income countries like Ethiopia is inefficient in providing sustainable credit facilities to the poor due to limited outreach and financial sustainability. Access to institutional credit, which contributes to the increase in investment, is very limited in Ethiopia particularly in Hawassa city. In other way, Samuel (2011) found that financial services accessible to the rural poor might have the potential to efficiently contribute to income generation, food security and poverty alleviation.

Even if the institutional sustainability and outreach of micro finance institution is burring agenda, few research has been conducted same topic in other parts of Ethiopia. For instance, (Samuel, 2011), (Reta, 2011); (Alemayehu, 2010), (Arsyad, 2005) and (Cletus \& Bilge, 2014) then suggested that institutional outreach and 
sustainability has positive influence on organizational performance of Omo microfinance institution in particular and contributes to the economic development of the nations.

But no research has been conducted in OMFI Hawassa branch with the same topic and the researcher has information about the problems related to institutional outreach and sustainability of OMFI in the city. This is why the researchers have motivated to conduct this research work.

\subsection{Objectives of the Study}

The general objective of this study is to assess the institutional outreach and sustainability of Omo microfinance institution at Hawassa.

Following general objective, the specific objectives of Study are:

1) To assess factors affecting outreach \& sustainability of OMFI Hawassa Branch

2) To assess the sustainability and outreach level of OMFIs Hawassa branch.

3) To assess saving mobilization services of OMFI in building sustainable and outreach

\subsection{Literature Review}

\subsubsection{Concept of Financial Sustainability}

When the microfinance concept begun exhibiting significant growth trends policy makers and other interested parties including donors started advocating for profitability from these institutions. Financial Sustainability is a key and arguably the most significant dimension of microfinance sustainability. Financial sustainability is the ability to continue with the microfinance objectives without sustained donor aid. Financial sustainability can also be explained by the ability of a Microfinance Institution in covering operational as well growth expenses from income derived from its own activities. An OMFI is said to be operationally sustainable if it can absorb its operation expenses from its own operations even if it is not subsidized. Financial Self-sufficiency on the other hand is when an OMFI is able to its operational and financing costs at market prices (Adeno, 2007).

According to study by (Arsyad, 2005), MFI self-sufficiency can be equated to nonprofit equivalent of profitability. A MFI that is able to cover the cost on non- cash expenses including the cost of inflation and at the same time has the ability to continue its operations without grants or subsidized inputs is said to have attained selfsufficiency In this study, the researcher uses OSS ratio to measure Microfinance financial sustainability.

Pursuit of financial sustainability has necessitated some MFIs to adopt approaches such as the gathering of Market intelligent and introduction of cost cutting measures aimed to checking the market forces and increasing efficiency which eventually leads to sustainability (CGAP, 2016).

Poverty alleviation has been one of the key development challenges over the decades in most developing economies. One of the identified key constraints faced by the poor is lack of access to formal credit. Microfinance institutions were established to fill the gap of scarce finance resources by providing funds to the poor and lower income group to alleviating poverty and enhance their business activities. Different approaches have been employed in alleviating poverty; the one is provision of credit for targeted poor. Credit is considered to be an essential input to increase productivity (Nawai and Shariff, 2013).

\subsubsection{Concept of Outreach}

Microfinance outreach is viewed in two major aspects; number of poor people microfinance can reach (Depth) and number of people served by MFI without necessarily considering their poverty levels (Breadth). In other words the depth of microfinance can be viewed in light of poverty levels of the people reached. This aspect can also be referred to as the social impact objective of Microfinance since it views Microfinance as a poverty alleviation tool. Proponents of this definition argue that a financial institution that disregard the economic status of the clients or does not consider the poor in their lending or financial services provision is no longer microfinance but rather a bank (Adeno, 2007).

On the other hand, outreach in terms of breadth can be defined as the scale of the microfinance institution in question without necessarily putting into consideration the economic status of the person. MFIs breadth can be defined as the ability of a MFI to reach a wide range of clients (Befekadu, 2007).

Other Scholars such as Smoradova (2010) and Samuel (2008) argue that in the microfinance field large number of clients in good standing enhance financial sustainability. The Institutions are Concerned about advancing access to a wider net clients not adequately served, further arguments suggest that sustainability is a means to attain outreach. Bearing in mind the possibility of MFIs services not reaching the majority of the poor populations, research and scholars have demonstrated that they are likely to benefit from the spillover effects. Some of such spillovers are manifested through employment opportunities, higher standards of living by family members and associates accruing to those establish enterprises and other income generating activities from micro credits advanced (AEMFI, 2009). 


\section{Methodology}

2.1 Research Design and Approach

Research Design: This study was employed research descriptive research design because the objective of this study was to describe institutional sustainability and outreach of OMFI Hawassa branch.

Research Approach: The study also employed mixed research approach due to qualitative and quantitative nature of the data.

\subsection{Data type and source, Methods Collection and Analysis}

Data type and source: This study was conducted based on both primary and secondary data types. The primary data sources were employees of OMFI but secondary data sources were Annual reports of OMFI and other published and unpublished materials.

Methods Collection and Analysis: The primary data were collected through structured questionnaires. After collection of the necessary data, it has been analyzed through descriptive statistics and presented in table form

\subsection{Target Population, Sample Size and Sampling Techniques}

Target Population: Target population of the study was 100 employees of OMFI Hawassa Branch

Sample Size and Sampling Techniques: The sample size for this study was 80 respondents drawn from the total population of 100 OMFI Hawassa branch using simple random sampling technique.

Sample size determination: Sample size of study was determined using formula (Yamane, 1967) and calculated below.

$$
\begin{gathered}
n=\frac{N}{1+e^{2} * N} \\
\text { Where: } \mathrm{n}=\text { sample size } \\
\mathrm{N}=\text { population size } \\
\mathrm{e}=\text { Precision level or sampling error }=0.05
\end{gathered}
$$

In order to take the sample from 100 employees of OMFI Hawassa by applying the above formula as follow:

$$
n=\frac{100}{1+(0.05)^{2} * 100}=80
$$

\subsection{Ethical consideration}

Ethical consideration: The ethical considerations such as voluntary participation of respondents, no harm to participants, confidentiality of data, and privacy of participants involved in this study have been given attention by the researchers.

\section{Presentation of Results}

\subsection{Introduction}

In order to conduct data analysis, the researcher distributed eighty (80) questionnaires to respondents. Out of the 80 questionnaires distributed, sixty (60) questionnaires were correctly filled and returned. This implies that the response rate of the research was seventy five percent $(75 \%)$ which indicates more than half of respondents were participated in the process of data collection. Then, the descriptive statistical analysis has done using the statistical package for social science version 23.0 based on 60 questionnaires properly collected.

\subsection{Reliability Test:}

\begin{tabular}{|c|c|}
\hline Cronbach's Alpha & No. of Items \\
\hline 0.703 & 14 \\
\hline
\end{tabular}

Table 1: Reliability Test of the study

Source: Personal survey, 2019

From the above table1, the value for Cronbach's Alpha $(\alpha)$ was 0.703 for all items. When these calculated reliability value is more 0.70 which acceptable, and compared with the minimum value of alpha 0.70 advocated by Cronbach's (1951), then the responses generated for all of the variables 'used in this research were reliable enough for data analysis. This implies that the data incorporated in SPSS version 23.0 is reliable and can be base for analysis. 


\subsection{Factors affecting outreach \& sustainability of OMFI Hawassa Branch}

\begin{tabular}{|c|c|c|c|c|}
\hline Items & 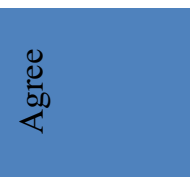 & 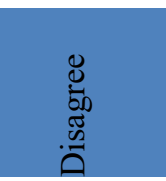 & 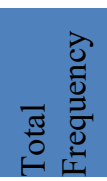 & 竞 \\
\hline $\begin{array}{l}\text { Nature of loan extended to customers is affects the } \\
\text { outreach and sustainability of your MFI. }\end{array}$ & $60(100.0 \%)$ & $0(0 \%)$ & 60 & $100 \%$ \\
\hline $\begin{array}{l}\text { Poor loan management has negative affect the } \\
\text { outreach and sustainability of your MFI. }\end{array}$ & $48(80.0 \%)$ & $12(20.0 \%)$ & 60 & $100 \%$ \\
\hline $\begin{array}{l}\text { Flexibility of loan repayment schedule extended to the } \\
\text { customers has effect on the sustainability of turnover } \\
\text { of your MFI }\end{array}$ & $47(78.3 \%)$ & $13(21.7 \%)$ & 60 & $100 \%$ \\
\hline $\begin{array}{l}\text { Consequence of loan defaulting faced by customers } \\
\text { has undesirable effect on the sustainability of your } \\
\text { MFI }\end{array}$ & $60(100.0 \%)$ & $0(0 \%)$ & 60 & $100 \%$ \\
\hline $\begin{array}{l}\text { Per customer outstanding has effect on outreach and } \\
\text { sustainability of your MFI }\end{array}$ & $44(73.3 \%)$ & $16(26.7 \%)$ & 60 & $100 \%$ \\
\hline
\end{tabular}

Table 2: Factors affecting outreach \& sustainability of OMFI Hawassa branch

Source: Personal survey, 2019

As it can be easily seen from the above table 2, the nature of loan has its own consequences on sustainability and outreach refilled 60(100\%) respondents agreed that the nature of loan is one of the factors affecting sustainability and outreach. Poor loan management as one factor affecting the outreach and sustainability of OMFI. Because, out of 60 sample respondents, $48(80.0 \%)$ agreed that poor loan management has negative affect the outreach and sustainability OMFI but only $12(20.0 \%) \%$ disagree with statement poor loan management has negative affect the outreach and sustainability. Flexibility of loan repayment also as a one of factors affecting sustainability and outreach. Because, 47 (78.3\%) agree with flexibility of loan repayment schedule extended to the customers has effect on the sustainability of turnover of OMFI but, 13(21.7\%) who disagreed with statement flexibility of loan repayment schedule extended to the customers has effect on the sustainability of turnover of OMFI. The consequences of loan defaults faced its own magnitudes on sustainability and outreach fill up 60(100\%) respondents agreed that the nature of loan is one of the factors affecting sustainability and outreach. but no any respondent opposed the statement as it has supported by $0(0 \%)$ disagree with statement. Finally, when it comes to per customer outstanding as one of factors affecting the outreach and sustainability of OMFI, majority of the respondents $44(73.3 \%)$ agreed on the statement that stated per customer outstanding as one of factors affect the outreach and sustainability of OMFI whereas $16(26.7 \%)$ of the respondents disagreed with the statement.

\subsection{The level of sustainable and outreach of OMFI of Hawassa branch}

\begin{tabular}{|c|c|c|c|c|c|c|c|}
\hline Items & 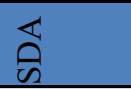 & 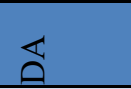 & Z & $\underset{4}{\longleftarrow}$ & $\ll$ & $\begin{array}{ll}\text { 퓨 } & - \\
0 & 0 \\
0 & 0 \\
\end{array}$ & $\stackrel{\text { त्ञ }}{\circ}$ \\
\hline $\begin{array}{l}\text { An increase in average size of loan } \\
\text { extended to customers has positive } \\
\text { effect the sustainability and outreach of } \\
\text { OMFI }\end{array}$ & $2(3.3 \%)$ & $5(8.3 \%)$ & $0(0)$ & $\begin{array}{l}27 \\
(45 \%)\end{array}$ & $\begin{array}{l}26 \\
(43.3 \%)\end{array}$ & 60 & $100 \%$ \\
\hline $\begin{array}{l}\text { A decrease in cost per borrower has } \\
\text { positive influence on the level } \\
\text { sustainability and outreach of OMFI }\end{array}$ & $3(5 \%)$ & $5(8.3)$ & $1(1.7 \%)$ & $\begin{array}{l}27 \\
(45 \%)\end{array}$ & $\begin{array}{l}24 \\
(40 \%)\end{array}$ & 60 & $100 \%$ \\
\hline $\begin{array}{l}\text { An increase number of active } \\
\text { borrowers has affected the level } \\
\text { sustainability and outreach of OMFI }\end{array}$ & $2(3.3 \%)$ & $\begin{array}{l}1 \\
(1.7 \%)\end{array}$ & $8(13.8 \%)$ & $\begin{array}{l}18 \\
(30 \%)\end{array}$ & $\begin{array}{l}31 \\
(51.7 \%)\end{array}$ & 60 & $100 \%$ \\
\hline $\begin{array}{l}\text { Competition of interest level with } \\
\text { banks has affected the level } \\
\text { sustainability and outreach of OMFI }\end{array}$ & $2(3.3 \%)$ & $5(8.3 \%)$ & $1(1.7 \%)$ & $27(45 \%)$ & $\begin{array}{l}24 \\
(40 \%)\end{array}$ & 60 & $100 \%$ \\
\hline $\begin{array}{l}\text { An increased number of branches has } \\
\text { ppositive sustainability and outreach } \\
\text { of OMFI }\end{array}$ & 0 & 0 & $2(3.3)$ & $27(45 \%)$ & $31(51)$ & 60 & $100 \%$ \\
\hline
\end{tabular}

Table 3: The level of sustainable and outreach of OMFI of Hawassa branch

Source: Personal survey, 2019

The above table shows that the level of sustainable and outreach of OMFI Hawassa branch measured on five 
point Likert scale is good on average. Hence, most of the respondents agreed on the statements such as; an increase in average size of loan extended to customers 53(88.3\%), a decrease in cost per borrower has positive influence $51(85 \%)$, an increase number of active borrowers $49(81.7 \%)$, competition of interest level with banks $51(85 \%)$ and an increased number of branches $58(96 \%)$ has positive implication of sustainability and outreach of OMFI respectively.

\subsection{Saving mobilization services of OMFI as a means of building sustainable and outreach}

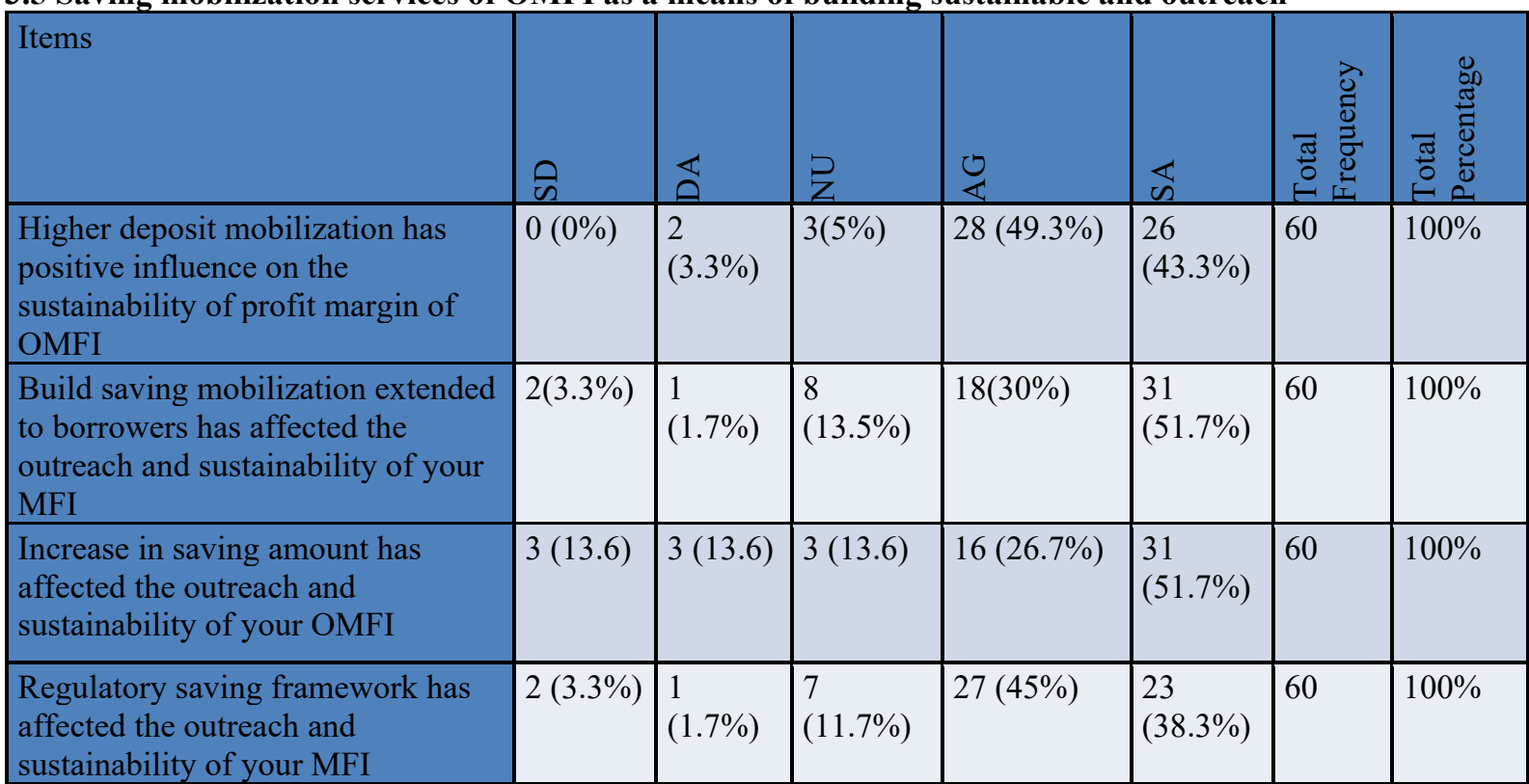

Table 4: Saving mobilization services of OMFI as a means of building sustainable and outreach

Source: Personal survey, (2019)

As displayed in the following table 4, saving mobilization services of OMFI as a means of building sustainable and outreach is positive on average as far as the most of respondents agreed on the statements such as; higher deposit mobilization has positive influence on the sustainability of profit margin of OMFI 54(92.6\%), build saving mobilization extended to borrowers has affected the outreach and sustainability $49(81.7 \%)$, increase in saving amount has affected the outreach and sustainability $47(78.4 \%)$ and regulatory saving framework has affected the outreach and sustainability 50(83.3\%) of your MFI respectively.

\section{Conclusion}

Conclusion is the process of making generalization based on findings of sample to total population. Therefore, the findings revealed from this study were generalized to all OMFIs as follow:

With regards to factors influencing outreach and sustainability of OMFI, the researcher can conclude that nature of loan extended to customers, poor loan management., flexibility of loan repayment schedule extended to the customers, consequence of loan defaulting faced by customers, and per customer outstanding has effect on outreach and sustainability of OMFI as far as most of the respondents expressed on the statement stated in Likert scale to measure.

When comes to level sustainable and outreach of OMFI, the researcher was concluded that in increase in average size of loan extended to customers has positive effect the sustainability and outreach of OMFI, decrease in cost per borrower has positive influence on the level sustainability and outreach of OMFI, increased number of active borrowers has affected the level sustainability and outreach of OMFI, competition of interest level with banks has affected the level sustainability and outreach of OMFI, and increased number of branches has positive sustainability and outreach of OMFI.

Level of sustainability and institutional outreach level is increased by higher deposit mobilization, build saving mobilization extended to borrowers, increase in saving amount, and regulatory saving framework for the reason most of the respondents expressed the level of agreement.

\section{Direction for the Further Research}

1) Originally, this study focused only on assessing the institutional sustainability and outreach of OMFI Hawassa city. Consequently, the findings of this study may be difficult to generalize about all MFIs in all regional regions and at national.

2) Hence, this study will be improved if it will be done, at other regions and national level by comparing the 
factors affecting operational effectiveness of OMFI by increasing sample size.

3) It can adopt model to assessing the institutional sustainability and outreach in Regions and country level which may increase the level of reliability of findings as far as the current study only used descriptive statistics for analyzing data collected from questionnaire and documents of OMFI.

4) Also can be done on the same topic by employing the econometric model by scientifically discuss the determinants of OMFI institutional sustainability and outreach based audited financial statement as the current study does not concentered on audited financial statements and not employing econometric model in analyzing data.

\section{Reference}

Alemayehu Yirsaw. (2008). The performance of Micro Finance Institutions in Ethiopia: A case of six microfinance institutions Addis Ababa, April, 2010.

AEMFI .(2009). Financial Needs of Micro and Small Enterprise (MSE) Operators in Ethiopia' Occasional Paper No. 24

Arsyad, L .(2005). An assessment of Microfinance Institution performance: The Importance of Institutional Environment‘. Gadjah Mada International Journal of Business, September-December 2005, vol. 7, No. 3, pp, $391-427$

Beaudry, S. (2008). Microfinance: A guide for grant makers.. [Online]Available at: http://www.gwob.net/news/GWOB Microfinance Guide.pdf [Accessed 6, 1, 2017].

Adeno K.(2007). Outreach and Sustainability of the Amhara Credit and Saving Institution (ACSI), Ethiopia. A Masters Thesis; Department of International Environment and Development Studies (Noragric) Norwegian University of Life Sciences (UMB), May 2007.

Befekadu B. Kereta .(2007). Outreach and Financial Performance Analysis of Microfinance Institutions in Ethiopia. African Economic Conference United Nations Conference Center (UNCC), Addis Ababa, Ethiopia 15-17 November 2007.

CGAP, .(2016). Measuring microcredit delinquency

Cronbach's, L. J. (1951), “Coefficient alpha and the internal structure of tests": Psychometric, 16, pp.297-334.

Nawai, N. and Shariff, M. N. M. (2013). Loan Repayment Problems in Microfinance Programs that use Individual Lending Approach: A Qualitative Analysis. Journal of Transformative Entrepreneurship, 1(2), pp. 93-99.

Reta, F. (2011). Determinate of Loan Repayment Performance: A Case Study of The Addis Credit and Saving Institution (ADCIS) In Addis Ababa.

Samuel Setargie Amera (2008). Credit Default Risk and Its Determinants of Microfinance Industry in Ethiopia.

Samuel, S. A. (2011). Credit default risk and its determinants of microfinance industry in Ethiopia.

Smoradova, B. (2010). History of microfinance and comparison of Grameen Bank and BancoSol..[Online]Availableat:http://www.grameeninfo.org/index.php?option=com_content\&task=view\&i $\mathrm{d}=26 \&$ Itemid=175. [Accessed 01 2017].

Taro Yamane (1967). Introduction to statistics $2^{\text {nd }}$ Edition 